\title{
Jurist-Diction
}

Volume 1 No. 1, September 2018

Article history: Submitted 2 August 2018; Accepted 15 August 2018; Available online 3 September 2018

\section{REMEDIES DALAM PUTUSAN ICSID DALAM SENGKETA INVESTASI INTERNASIONAL}

\author{
Amelia Maulanasari \\ ameliamaulanasari@gmail.com \\ Universitas Airlangga
}

\begin{abstract}
A dispute arising from an investment process involving two or more countries may arises from an investment agreement agreed upon by the parties. If one of the parties breaches the agreement, or it may be said to be a default, then by the arbitration clause in the agreement, the parties will automatically resolve the dispute to the arbitration, such as the ICSID arbitration. Therefore, the existence of arbitration clause in the context of investment agreement (BIT) is very necessary. The legal product of ICSID arbitration is a binding decision for the parties. In a judgment it should contain a remedies set by the arbitrator in the arbitration. Remedies in ICSID arbitration are two forms: pecuniary remedies and non-pecuniary remedies. The remedies are given as compensation or orders to do something for the losses faced by the opponent party, so the losing party have to pay compensation for the default actions they have done. Furthermore, the form of remedies that have been issued to the losing party shall be executed by the losing party in their state territory. If the remedies are imposed for Indonesia as a losing party, the arbitration award shall first be recognized (recognition) and done the enforcement under Act No. 30 of 1999 on Alternative Dispute Settlement. Determination of remedies is determined through several applicable compensation calculation methods and applicable legal principles of compensation, such as prompt, adequate, and equitable principle; and damnum emergens and lucrum cessans.
\end{abstract}

Keywords: Arbitration; ICSID; Remedies; Award; Compensation.

\begin{abstract}
Abstrak
Suatu sengketa yang timbul dalam proses investasi yang meliputi dua atau lebih negara dapat bermula dari sebuah perjanjian investasi yang telah disepakati oleh para pihak. Apabila salah satu pihak melakukan pelanggaran atas perjanjian yang telah dibuatnya, atau dapat dikatakan wanprestasi, maka dengan adanya klausula arbitrase dalam perjanjian tersebut, secara otomatis para pihak akan menyelesaikan sengketanya kepada arbitrase, seperti arbitrase ICSID. Oleh karena itu adanya klausula arbitrase dalam konteks perjanjian investasi (BIT) tersebut sangat diperlukan. Produk hukum dari arbitrase ICSID adalah sebuah putusan yang bersifat mengikat bagi para pihak. Dalam sebuah putusan hendaknya termuat sebuah remedies yang telah ditetapkan oleh arbitrator dalam arbitrase. Remedies dalam arbitrase ICSID terdapat dua bentuk yaitu pecuniary remedies dan non-pecuniary remedies. Remedies tersebut diberikan sebagai kompensasi atau perintah untuk melakukan sesuatu atas kerugian yang dialami pihak lawan, sehingga pihak yang kalah wajib melakukan ganti rugi atas tindakan yang telah dilakukannya. Selanjutnya, bentuk remedies yang telah dijatuhkan kepada pihak yang kalah tersebut wajib dilaksanakan oleh pihak yang kalah tersebut. Apabila remedies tersebut dijatuhkan untuk Indonesia sebagai pihak yang kalah, maka terlebih dahulu putusan arbitrase tersebut mendapatkan pengakuan (recognition) dan pelaksaanaan (enforcement) berdasarkan Undang-Undang Nomor 30 Tahun 1999 tentang Alternatif Penyelesaian Sengketa. Penentuan remedies ditentukan melalui beberapa metode perhitungan kompensasi yang berlaku dan prinsip-prinsip hukum mengenai kompensasi yang berlaku.
\end{abstract}

Kata Kunci: Arbitrase; ICSID; Remedies; Putusan; Kompensasi. 


\section{Pendahuluan}

Permasalahan investasi yang terjadi antar host-state dan investor memungkinkan untuk menjadi obyek sengketa dalam lingkup International Centre for Settlement Investment Dispute (ICSID). Hal ini sesuai dengan pengaturan ICSID Convention, Article 26 (1). Arbitrase ICSID, pada umumnya muncul pada perjanjian atau kontrak investor antar negara yang menyatakan secara tegas dalam perjanjian tersebut bahwa segala macam permasalahan hukum yang timbul akibat dari perjanjian tersebut akan mengacu pada ICSID untuk penyelesaian sengketa. ${ }^{1}$ Dengan tambahan, bahwa kedua pihak, host-state dan home-state merupakan anggota dari ICSID Convention yang mempunyai batas yurisdiksi tertentu.

Dalam historisnya, Indonesia pertama kali berhadapan dengan sengketa didalam ICSID dalam sengketa construction and operation pada kasus Amco Asia Corporation (U.S), PT. Amco (Indonesia), Pan American Development Limited (British) sebagai claimants dan Indonesia sebagai respondents, pada tahun 1981.

Pada dasarnya, pemerintah Indonesia telah meratifikasi ICSID Convention, yang dituangkan dalam bentuk undang- undang, yaitu Undang- Undang Republik Indonesia No. 5 Tahun 1968 tentang Penyelesaian Perselisihan Antara Negara dan Warga Negara Asing Mengenai Penanaman Modal. Hal ini ditegaskan dalam Pasal 1 Undang- Undang ini yang menyatakan bahwa Indonesia telah menyetujui atas Convention on the Settlement of Investment Dispute Between States and Nationals of Other States. Maka dari berlakunya undang- undang tersebut, dapat disimpulkan bahwasanya Indonesia telah meratifikasi arbitrase internasional dalam aspek investasi melalui ICSID. Sekalipun Pemerintah Republik Indonesia telah meratifikasi ICSID Convention, tidak berarti, secara otomatis setiap sengketa antara investor asing dengan Pemerintah Indonesia harus diselesaikan oleh dewan arbitrase ICSID. ${ }^{2}$

1 Consent of the parties to arbitration under this Convention shall, unless otherwise stated, be deemed consent to such arbitration to the exclusion of any other remedy. A Contracting State may require the exhaustion of local administrative or judicial remedies as a condition of its consent to arbitration under this Convention. (Article 26 (1) ICSID Convention).

2 Lydia Kaunang, Penyelesaian Sengketa Penanaman Modal Menurut Undang- Undang Nomor 25 Tahun 2007, Lex Privatum Vol.V/No.6 (2017)[106]. 
Dalam kondisi bahwa negara tidak mematuhi atas putusan arbitrase yang telah dijatuhkan, maka investor dapat mencari pelaksanaan ke pengadilan nasional dan menempatkan asset komersial dalam sebuah penegakan yurisdiksi. Dalam melakukan eksekusi putusan arbitrase ICSID, setiap para pihak contracting states diwajibkan untuk menaati keputusan yang telah dicantumkan dalam putusan arbitrase sebagai putusan akhir (final judgements). Atas putusan arbitrase ICSID ini hanya mengikat kepada para pihak yang bersengketa, tidak mengikat kepada pihak ketiga. Ketentuan ini mensyarakatkan untuk para losing party menaati atas putusan arbitrase secara langsung.

Menurut pengaturan hukum nasional, terutama Undang- Undang Nomor 30 Tahun 1999 tentang Alternatif Penyelesaian Sengketa, pada Pasal 65 disebutkan bahwa yang berwenang menangani masalah pengakuan dan pelaksanaan putusan arbitrase internasional adalah Pengadilan Negeri Jakarta Pusat. Sehingga dalam menjalankan eksekusi putusan arbitrase atau melaksanakan remedies atas sengketa yang mencakup wilayah negara Republik Indonesia, harus melalui putusan Pengadilan Negeri Jakarta Pusat terlebih dahulu. Namun pada prakteknya, mayoritas putusan arbitrase tersebut tidak dijalankan oleh pihak yang kalah dengan berbagai keberatan, termasuk dengan bentuk remedies yang dijatuhkan.

Oleh karena itu, berdasarkan latar belakang tersebut, adanya ketidakpastian hukum atas pelaksanaan remedies atau pemberlakuan eksekusi atas putusan arbitrase dalam penyelesaian sengketa, penelitian ini membahas tentang Remedies dalam Putusan ICSID Dalam Sengketa Investasi Internasional.

\section{Arbitrase ICSID}

Arbitrase Investasi Internasional dalam hal ini lingkup arbitrase ICSID, dalam meliputi ranah publik dan privat. Dapat dikatakan dalam ranah publik karena salah satu pihak dapat berupa suatu negara. Dimana negara memiliki sifat publik dalam penyelesaian sengketa. Sedangkan dikatakan dalam ranah privat, hal ini terjadi dalam hal para pihak berupa individual atau dalam bentuk entitas lain. Hal yang terpenting yaitu para pihak tersebut telah menyepakati untuk penyelesaian 
sengketa ke arbitrase yang termuat dalam klausula arbitrase pada perjanjiannya (BIT). Sehingga hal ini termasuk dalam jurisdiksi arbitrase ICSID yaitu segala permasalahan hukum yang timbul dari para pihak, seperti yang telah dinyatakan dalam Article 25 (1) ICSID Convention.

"The jurisdiction of the Centre shall extend to any legal dispute arising directly out of an investment, between a Contracting State (or any constituent subdivision or agency of a Contracting State designated to the Centre by that State) and a national of another Contracting State, which the parties to the dispute consent in writing to submit to the Centre".

Dalam menentukan penyelesaian sengketa investasi diperlukan penegasan pada perjanjian investasi para pihak perihal penyelesaian sengketa yang akan digunakan sebagai penentuan jurisdiksi penyelesaian sengketa tersebut. Sedangkan dalam lingkup arbitrase ICSID sendiri telah diatur mengenai cara untuk menyerahkan penyelesaian sengketa melalui arbitrase pada ICSID Convention. Atas ketentuan Article 26 dalam ICSID Convention tersebut, maka dalam menyerahkan penyelesaian sengketa para pihak kepada arbitrase, terlebih dahulu harus disepakati tertulis dalam perjanjian. Apabila secara jelas klausula arbitrase tersebut telah tertulis, maka dalam hal ini arbitrase ICSID akan memiliki jurisdiksinya dalam menyelesaikan sengketa tersebut.

\section{Remedies Dalam Artbitrase Investasi Internasional}

Eksistensi remedies berawal dari timbulnya sengketa yang terjadi antara para pihak contracting states yang kemudian dibawa di dalam persidangan. Dalam arbitrase, pada dasarnya sebelum adanya persidangan sengketa tersebut terlebih dahulu para pihak akan menentukan pilihan hukum yang disepakati, yang nantinya akan digunakan oleh dalam persidangan. Pilihan hukum merupakan salah satu syarat wajib yang harus ada di dalam kontrak, khususnya kontrak bisnis yang bersifat internasional, karena para pihak dipertautkan dengan beberapa hukum yang berbeda. ${ }^{3}$ Adanya prinsip pemilihan hukum yang akan digunakan dalam klausula arbitrase

${ }^{3}$ Indra Tri Kurniawan, Arbitrase Internasional Sebagai Pilihan Forum dalam Penyelesaian Sengketa Kontrak Kerjasama Internasional, Skripsi Fakultas Hukum Universitas Airlangga (2012).[23]. 
pada investment agreement sangat diperlukan guna menghindari timbulnya conflict of law antara para pihak bersengketa. Sehingga terdapat suatu kepastian hukum untuk menyelesaikan masalah yang timbul. Adanya prinsip pemilihan hukum (choice of law) disini akan berlaku pula dalam kedudukan remedies yang akan dilaksanakan oleh negara pihak yang kalah, baik pelaksanaan remedies dilakukan dengan mengikuti hukum host state atau home state.

Pada dasarnya, ICSID Convention sendiri tidak mengatur secara spesifik mengenai remedies atau ganti rugi atas suatu sengketa investasi, baik berupa bagaimana bentuk remedies tersebut berlaku, hingga bagaimana parameter suatu remedies tersebut dapat diterapkan dalam sengketa investasi. Maka dari itu, disini masih terjadi kekosongan pengaturan hukum mengenai remedies dalam lingkup internasional, begitu pula dalam lingkup nasional. Biasanya dalam menentukan remedies, hal ini akan berdasar pada pertimbangan - pertimbangan hukum para arbitrator dan melalui beberapa metode perhitungan yang dipilih, seperti metode DCF (Discounted Cash Flow).

\section{Bentuk-Bentuk Remedies Yang Diterapkan oleh ICSID Award}

Pada dasarnya, remedies dalam lingkup akibat dari adanya suatu putusan pengadilan seperti ICSID Award, yang memberikan bentuk ganti rugi atas damages yang ditimbulkan. Bentuk-bentuk remedies dalam lingkup ganti kerugian yang paling umum diterapkan dalam pengadilan ICSID, dapat berupa pecuniary remedies atau non pecuniary remedies. ${ }^{4}$

\section{Pecuniary Remedies}

Atau lebih sering disebut sebagai monetary remedies merupakan suatu bentuk remedies yang menekankan pada kompensasi dalam bentuk moneter. Seringkali diterapkan dalam hal ganti kerugian yang dialami oleh pihak yang dirugikan dalam sengketa. Sehingga, pihak pihak yang kalah wajib membayar ganti kerugian atas kerugian dalam proses investasi tersebut. Terkait pecuniary remedies pada dasarnya

\footnotetext{
4 United Nations, Investor-State Dispute Settlement (UNCTAD Series on Issues In International Investment Agreements II).
} 
telah diakui dalam ICSID Convention untuk wajib melaksanakan kewajiban moneter dalam ganti rugi suatu damages yang ditimbulkan (Article 54 (1).

Article 54 (1) ICSID Convention

"Each Contracting State shall recognize an award rendered pursuant to this Convention as binding and enforce the pecuniary obligations imposed by that award within its territories as if it were a final judgment of a acourt in that State”.

Dalam ketentuan tersebut disebutkan bahwa contracting state wajib melaksanakan kewajiban pecuniary nya yang dianggap sebagai kompensasi ganti kerugian damages yang dijatuhkan dalam putusan arbitrase. Mengenai bagaimana pelaksanaan pecuniary obligations tersebut akan bergantung pada kedaulatan yang dimiliki oleh suatu negara yang menerima dampak remedies ini. Namun, pelaksanaan ini bersifat wajib sebab kedudukan dari putusan arbitrase ICSID memiliki sifat binding bagi para pihak bersengketa.

\section{Non-Pecuniary Remedies}

Dalam konsep non-pecuniary remedies ini terdapat dua ruang lingkup remedies yang akan diberikan, yaitu dalam bentuk provisional measures, restitusi asset, dan perintah untuk melakukan tindakan tertentu. Apabila dalam hal provisional measures maka berarti investor mungkin memerlukan tindakan mendesak yang harus dilakukan untuk menghalangi langkah yang merugikan dari negara yang menunggu resolusi dari sengketa tersebut. ${ }^{5}$ Sehingga disini investor membutuhkan suatu tindakan untuk menghindari tindakan yang akan lebih merugikan dari pihak lawan. Tindakan dalam provisional measures ini hanya dapat dilakukan apabila dibutuhkan dan dirasa mendesak, dengan tujuan untuk memberikan keefektifan jalannya arbitrase dan menghindari pelanggaran lain dalam suatu sengketa. Hal ini telah dinyatakan dalam Article 47 ICSID Convention:

Eksistensi remedies sebagai ganti kerugian yang timbul pada putusan arbitrase, hanya bisa digunakan oleh pihak yang kalah berdasarkan ICSID Convention saja

5 Sylvia Noury, Remedies against states in investor-state arbitration - more bark than bite?, Freshfields Bruckhaus Deringer: BIICL Annual Conference (2009). [9]. 
yang menyatakan bahwa putusan mengikat bagi para pihak. Namun, berdasarkan ICSID Convention, tidak diatur secara pasti mengenai bentuk remedies apa saja yang akan diberikan. Pada Article 54 (1) ICSID Convention dinyatakan mengenai kewajiban untuk pelaksanaan atas putusan arbitrase. Selain itu, dari Article 54 (1) tersebut, dinyatakan bahwa para pihak untuk melaksanakan pecuniary obligations yang telah ditentukan dalam putusan arbitrase investasi tersebut. Pernyataan tersebut merupakan hal yang salah apabila kita menyimpulkan bahwa ketentuan yang menyatakan bahwa pengadilan ICSID dimungkinkan tidak memberikan nonpecuniary remedies seperti perintah atas tindakan tertentu. ${ }^{6}$

Beberapa tribunal arbitrase telah menegaskan kekuatan mereka untuk memberikan remedies apa saja yang mereka anggap tepat dan telah memerintahkan remedies nonuang (non-pecuniary remedies), semata-mata atau dikombinasikan dengan kompensasi uang (pecuniary remedies). ${ }^{7}$ Dalam memilih remedies yang akan dituntut oleh pihak lawan, hal ini akan berhubungan dengan right to regulate, seperti negara Indonesia memiliki kedaulatan, terutama right to regulate, maka atas pelaksanaan non pecuniary remedies tersebut mengikuti hukum yang berlaku di Indonesia.

\section{Prinsip Remedies sebagai Kompensasi dalam Arbitrase Investasi Internasional Prinsip Prompt, Adequate, and Effective}

Prinsip ini menjadi prinsip standard arbitrase dalam menjatuhkan putusan yang memuat kompensasi. Hal ini telah menjadi pandangan United States, bahwa kompensasi yang bersifat prompt, adequate and effective harus dilaksanakan dan dibayarkan, namun hukum kebiasaan yang ada dalam hukum internasional pada umumnya akan lebih mendukung standar full compensation. ${ }^{8}$ Dimana dalam prinsip full compensation apabila akan mengaplikasikan konsep ini berarti dalam arbitrase akan menggunakan metode perhitungan kompensasi pada umumnya, seperti book

\footnotetext{
6 Op.Cit.

7 For details, see Ripinsky with Williams, 2008, pp.51-52 Op.cit, [143].

8 Kevin Smith, The Law Of Compensation For Expropriated Companies And The Valuation Methods Used To Achieve That Compensation, Paper Law \& Valuation: Professor Palmiter, 2001, dikutip pada https://users.wfu.edu/palmitar/Law\&Valuation/Papers/2001/Smith.htm pada 10 Januari 2017.
} 
value dan Discounted Cash Flow (DCF). Namun dalam hal ini belum ada definisi tetap mengenai full compensation itu sendiri.

\section{Prinsip Damnum Emergens dan Lucrum Cessans}

Lucrum cessans merupakan keadaan dimana kehilangan keuntungan dari pendapatakibat dari adanya suatu pelanggaran dari kontrak atau tidak dilakukannya sebuah prestasi (breach of contract).

Prinsip damnum emergens bersifat recoverable dan prinsip ini tidak berlaku pada penentuan nilai pasar dari sebuah asset. Kompensasi hanya untuk damnum emergens, akan tetapi hal ini akan menempatkan penggugat pada posisi sebelum menetapkan atau menutup kontrak. Sedangkan jika ditambah dengan lucrum cessans (keuntungan yang hilang), maka akan menempatkan penggugat dalam posisi ketika kontrak telah dilakukan. Dengan kata lain, hanya pemberian damnum emergens dan lucrum emergens untuk pelaksanaan full compensation. ${ }^{9}$

\section{Remedies pada Ekspropriasi}

Dalam sebuah klaim ekspropriasi aset, terdapat dua macam aspek yang dapat dimungkinkan terjadi dalam lingkup kompensasi. Aspek pertama, seperti yang diakui dalam hukum internasional, bahwa ketika sebuah negara mengekspropriasi aset, hal ini memiliki kewajiban untuk membayar kompensasi atas aset tersebut. Kewajiban ini menjadi suatu kewajiban yang substantif dalam perjanjian investasi para pihak. Kedua, yakni berhubungan dengan fakta dimana sebuah negara mengekpropriasi tetapi dinyatakan gagal untuk membayar kompensasi, yang mana hal ini telah menjadi kewajiban dalam perjanjiannya, maka tindakan seperti ini dapat dikategorikan sebagai wrongful act yang mana akan berlaku pula prinsip full reparation. Namun, besarnya kompensasi akibat dari masalah kewajiban substansif negara dalam ekspropriasi berbeda dengan bersarnya kompensasi

\footnotetext{
${ }^{9}$ Sergey Ripinsky dan Kevin Williams, Damages in International Investment Law, British Institute of International and Comparative Law: London (2008).[107].
} 
untuk reparation yang dimana negara mengekspropriasi dalam lingkup bahwa hal tersebut melanggar kewajiban yang diperjanjikan. ${ }^{10}$

\section{Penentuan Jumlah Kompensasi Oleh Arbitrase ICSID}

Dalam menentukan prosentase atau jumlah remedies yang dijatuhkan, arbitrase ICSID menggunakan beberapa metode sebagai acuan untuk memberikan remedies. Dimana pada umumnya arbitrase ICSID lebih sering memberikan remedies berupa kompensasi dengan menilai nilai dari aset investor. Beberapa metode tersebut antara lain: ${ }^{11}$

1. Metode Perhitungan Tradisional

Metode ini merupakan metode-metode yang telah diatur dalam World Bank Guidlines. Dalam jenis metode ini terdapat beberapa jenis tahap yang sering digunakan antara lain dalam bentuk nilai likuidasi (liquidation value); nilai penggantian (replacement value); nilai pembukuan (book value); discounted cash flow value (DCF).

Menurut Development Committee yang bekerjasama dengan World Bank Guidelines menyatakan bahwa kompensasi dengan metode ini tidak sesuai untuk kerugian spekulatif atau tidak tentu, atau untuk dugaan keuntungan yang tidak dapat diperoleh secara sah berdasarkan undang-undang dan peraturan negara host state.

2. Metode Perhitungan Lainnya

Jenis metode perhitungan lainnya menggunakan beberapa pendekatan yang beberapa telah diimplementasikan pada beberapa kasus ICSID. Misalnya, pendekatan comparable transaction ${ }^{12}$ dan pendekatan option. ${ }^{13}$ Dalam kasus

${ }^{10}$ Aby Cohen Smutny, Principles Relating to Compensation in The Investment Treaty Context, Op.Cit.[8].

${ }^{11}$ Ibid. [417].

${ }_{12}$ A comparable transaction is a method of valuing a company that is for sale. Comparable transactions considers the past sales of similar companies as well as the market value of publicly traded firms that have an equivalent business model to the company being valued. (dikutip dari Investopedia, Comparable Transaction, https://www.investopedia.com/terms/c/comparable-transaction.asp\#ixzz4zKv6rxc9 pada 24 November 2017).

${ }_{13}$ Pendekatan option mempelajari penggunaan alternatif yang dapat dilakukan terhadap aset yang bersangkutan, dan biaya dan manfaatnya. (CMS Gas Transmission Co v Argentina (Award) ICSID Case No ARB/01/8, 14 ICSID Rep 158, IIC 65 (2005, Orrego Vicuna P, Lalonde \& Rezek) para. 403, dalam Campbell McLachlan Qc, Laurence Shore, dan Matthew Weiniger Qc, International Investment Arbitration: Substantive Principles (Second Edition), Ibid.[ 420]. 
CMS Gas Transmission Co v Argentina dan CME Czech Republic BV v Czech

Republic yang menggunakan pendekatan comparable transaction.

Seperti dalam kasus Amco Asia Corp v Indonesia dalam ICSID yang mengadopsi metode DCF. Klaim tersebut timbul dari kontrak sewa hotel yang dilakukan selama tiga puluh tahun di Indonesia yang diambil alih setelah sebelas tahun. Arbitrase ICSID tersebut menemukan bahwa pihak Amco Asia berhak mendapatkan kompensasi atas hilangnya hak pengelolaan hotel. Dalam menentukan pecuniary remedies atau jumlah kompensasinya tersebut, diperlukan penerapan hukum Indonesia dan hukum internasional. Dalam membuat putusan terkait remedies, arbitrase ICSID merekomendasikan pengimplementasian metode DCF sebagai salah satu metode logis ditunjukkan bahwa tujuan kompensasi adalah menempatkan Amco Asia sebagai pihak yang menerima manfaat dari kontrak investasi tersebut. Selanjutnya dalam penerapannya, pada arbitrase menyatakan bahwa metode DCF tidak bersifat spekulatif, namun ICSID menemukan kelebihan seperti yang dinyatakan dalam putusannya bahwa dalam pernyataan diatas, dinyatakan metode DCF itu sendiri bergantung pada penerapan asumsi yang bersifat menghakimi. Metode DCF sekaligus merupakan metode yang fleksibel, yang memungkinkan penerapan faktor dan elemen dinilai relevan.

Selain itu dalam menjatuhkan suatu bentuk remedies dalam putusan, dapat juga berdasarkan pada legitimate expectations. Jika legitimate expectations merupakan sebuah kriteria, maka investor dapat berpendapat bahwa legitimate expectations akan dapat mewujudkan keuntungan yang diantisipasi selama masa konsesi.

\section{Mekanisme Pelaksanaan Putusan Arbitrase Investasi di Berbagai Negara Pelaksanaan Putusan Arbitrase Investasi di United States}

Bila melihat mekanisme pelaksanaan putusan arbitrase ICSID pada negara lain, seperti United Sates, pelaksanaan putusan arbitrase ICSID akan didasarkan pada Washington Convention. Berdasarkan Article 54 Washington Convention, disebutkan bahwa putusan ICSID dimaksudkan untuk menjadi setara dengan penghakiman terakhir di pengadilan contracting states (dalam hal ini United 
States). Namun, dalam Article 55 Washington Convention, memberikan pengecualian penting pada Article 54. Ketentuan ini mengabaikan keseluruhan pertahanan imunitas (sovereign immunity) bahwa sebuah negara dapat diadili di pengadilan dimana tempat pelaksanaan selama eksekusi (termasuk dalam lingkup pelaksanaan putusan ICSID). Beberapa negara (pihak yang dikalahkan) telah berhasil menghindari eksekusi atau non pecuniary remedies dengan berdasarkan klausul pertahanan sovereign immunity bagi negara di bawah hukum tempat eksekusi putusan ICSID tersebut. Seperti dalam pelaksanaan putusan ICSID dalam lingkup United States, terdapat kasus Liberian Eastern Timber Corp. v. Republic of Liberia, ${ }^{14}$ yang mempertahankan kedudukannya dalam pelaksanaan eksekusi melalui klausul sovereign immunity yang dimilikinya. ${ }^{15}$

\section{Pelaksanaan Putusan Arbitrase Investasi di United Kingdom (U.K.)}

Dalam pelaksanaan putusan atau eksekusi putusan ICSID dalam lingkup hukum negara U.K. bahwa implementasinya mendasarkan pada U.K. Sovereign Immunity Act of 1978. Dimana dalam U.K. Sovereign Immunity Act of 1978 tersebut terdapat klasifikasi khusus untuk eksekusi dilakukan, seperti halnya terkait monetary authority pada U.K. Contohnya, apabila putusan ICSID memberikan remedies kepada Bank Sentral untuk mengeksekusi asetnya (non pecuniary remedies), maka berdasarkan U.K. Sovereign Immunity Act of 1978, remedies ini tidak dapat dilakukan di lingkup hukum U.K karena Undang-Undang tersebut mengecualikan aset Bank Sentral untuk dieksekusi.

\section{Pelaksanaan Remedies Arbitrase Asing dalam Hukum Indonesia}

\section{Eksekusi Remedies dalam Hukum Nasional Indonesia}

Apabila kita melihat eksistensi remedies dalam hukum nasional Indonesia, dapat dilihat dari konsep ganti rugi yang berlaku dalam Kitab Undang-Undang

${ }^{14}$ Liberian Eastern Timber Corp. v. Republic of Liberia, ICSID Case No. ARB/83/2, (Award, Mar 31, 1986), 2 ICSID Rep. 346. The decisions of the U.S. courts in the enforcement proceedings in this case may be accessed at ICSID Rep. 384-96. (dikutip dalam Christopher F. Dugan and Don Wallace, Jr., Investor-State Arbitration, Oxford University Press (2017).[700].

15 Op.Cit.[700]. 
Hukum Perdata (KUHPer) atau Burgerlijk Wetboek (BW). Ganti rugi sendiri telah diatur dalam Pasal 1246 BW.

Menurut Purwahid Patrik, terdapat dua unsur kerugian, antara lain:

1) Kerugian yang nyata diderita (damnum emergens) meliputi biaya dan rugi;

2) Keuntungan yang tidak diperoleh (lucrum cessans) meliputi bunga. ${ }^{16}$

Namun adanya ganti rugi atas kepentingan yang tidak dapat dinilai dengan uang, seperti dalam bentuk non-pecuniary remedies dalam abitrase, telah diakui dalam Pasal 1601w KUHPerdata. Jadi yang dimaksud bukannya sifat dari kepentingan yang dirugikan, tetapi apakah yang dirugikan bisa dipulihkan dengan pembayaran ganti rugi sejumlah uang. Namun di luar hal-hal yang tersebut tadi biasanya ganti rugi non-ekonomis lebih sempurna bila diganti dengan sejumlah uang sebagai alat rehabilitasinya. Asal benar-benar jumlah ganti rugi tadi "efektif" banyaknya sesuai dengan perhitungan yang memungkinkan tercapainya hasil pemulihan yang mendekati keadaan semula. ${ }^{17}$

Dalam hal pelaksanaan remedies yang akan dilaksanakan oleh pihak yang kalah, dalam hukum nasional Indonesia, terlebih dahulu disyaratkan untuk adanya pengakuan atas putusan arbitrase tersebut ke Pengadilan yang telah diatur dalam Undang- Undang. Mengenai masalah pengakuan (recognition) dan pelaksanaan (enforcement) putusan arbitrase tersebut, dapat didasarkan pada Undang-Undang Nomor 30 Tahun 1999 tentang Arbitrase dan Alternatif Penyelesaian Sengketa.

Berdasarkan undang-undang tersebut, diatur bahwa yang mempunyai wewenang untuk pengakuan dan pelaksanaan putusan arbitrase berada pada wewenang Pengadilan Negeri Jakarta Pusat.

Pasal 65 Undang-Undang Nomor 30 Tahun 1999:

"Yang berwenang menangani masalah pengakuan dan pelaksanaan putusan Arbitrase Internasional adalah Pengadilan Negeri Jakarta Pusat”.

Dari ketentuan tersebut dapat dikatakan adanya sebuah monopoli terkait wewenang pengadilan, karena yang memegang wewenang tersebut hanya ada pada

${ }_{16}$ M. Tjoanda, Wujud Ganti Rugi Menurut Kitab Undang-Undang Hukum Perdata, Jurnal Sasi Vol. 16 No. 4: Jurnal Universitas Pattimura, Oktober-Desember (2010).[45].

17 Ibid.[49]. 
Pengadilan Negeri Jakarta Pusat. Atau dengan kata lain, kegiatan untuk melaksanakan (enforcement), di samping tentunya menangani masalah pengakuan (recognition) putusan arbitrase asing di Indonesia, telah dilimpahkan secara tersentralisir dan menjadi wewenang penuh dari Pengadilan Negeri Jakarta Pusat. ${ }^{18}$ Hal ini sama dengan yang dinyatakan oleh Z. Asikin Kusumah Atmadja, bahwa mengingat pentingnya dan luasnya persoalan yang timbul dengan substansi peraturan dalam bidang arbitrase ini, maka yang dianggap perlu untuk menyelesaikan persoalan ini adalah pihak Pengadilan Negeri Jakarta Pusat. ${ }^{19}$

Sehingga, pada dasarnya, di Indonesia sendiri belum terdapat kepastian hukum yang pasti mengenai kedudukan remedies dalam hukum nasional Indonesia. Karena, Indonesia hanya mengatur mengenai pengakuan dan pelaksanaan dari putusan arbitrase internasional yang menjadi syarat dari remedies dari putusan arbitrase investasi tersebut dilaksanakan pada Undang-Undang Nomor 30 Tahun 1999.

\section{Parameter Penerimaan dan Penolakan Remedies}

Suatu remedies dalam lingkup investasi akan termasuk dalam substansi putusan arbitrase ICSID. Dalam menghadapi sebuah remedies yang diterima oleh pihak yang dikalahkan, maka mereka akan menghadapi 2 (dua) pilihan atas remedies, yaitu diterima atau ditolak. Maka untuk menghadapi pilihan tersebut, suatu negara dapat memilih dengan mengukur kapasitasnya melalui kedaulatan negara yang dimilikinya. Karena tidak semua negara memiliki kedaulatan negara yang absolut, sehingga tidak serta merta remedies tersebut dapat berlaku atau mampu dilaksanakan oleh beberapa negara.

Atas kedaulatan negara yang dimiliki oleh suatu negara sebagai pihak yang dikalahkan dalam sengketa, kedaulatan tersebut memiliki batasan - batasan yang berbeda untuk setiap negara. Misalnya, Indonesia yang memiliki batasan kedaulatan negaranya dalam prinsip right of state to regulate. Indonesia akan

${ }_{18}$ Nurhadi, S.H, Pelaksanaan Putusan Arbitrase Internasional di Indonesia, Op.Cit, [46].

19 Sudargo Gautama, Undang-Undang Arbitrase Baru 1999, PT Citra Aditya Bakti (1999). [132]. 
memberikan pertimbangan hukum tersendiri untuk mempertimbangkan terkait dengan pelaksanaan remedies arbitrase investasi ICSID ini. Sehingga, Indonesia nantinya juga akan berdasarkan seperti pada prinsip ketertiban umum, atau prinsip legalitas agar pelaksanaan remedies tersebut tidak merugikan negara.

\section{Pelaksanaan Putusan Arbitrase Internasional Terkait Investasi di Indonesia}

Dalam hal pelaksanaan remedies dalam konteks hukum Indonesia, terlebih dahulu pihak yang bersengketa wajib mendaftarkan putusan arbitrase investasi tersebut ke pengadilan Indonesia. Pendaftaran tersebut dalam rangka agar putusan arbitrase tersebut diakui dan dapat dilaksanakan di wilayah hukum Indonesia. Selanjutnya, Undang-Undang Nomor 30 Tahun 1999 mengatur bahwa pendaftaran putusan arbitrase dapat dilakukan dibawah kewenangan Pengadilan Negeri Jakarta Pusat.

Pada kasus Amco Asia, sesuai dengan klausula dalam permohonan izin lisensi investasi asing yang dijalankan, kasus ini dibawa dalam proses ICSID. Dimana dalam kasus ini, Amco Asia menantang akan adanya pengambilalihan hotel dan pencabutan izin investasi. Arbitrase ICSID menemukan bahwa Indonesia bertanggung jawab atas perampasan hotel tersebut oleh pasukan militer dan polisi. ${ }^{20}$ Maka dalam hal ini, Indonesia berniat untuk membatalkan putusan arbitrase tersebut, dengan meminta pembentukan komite ad hoc, seperti yang diatur dalam Article 52 ICSID Convention.

\section{Akibat Hukum Penolakan Remedies di Indonesia}

Bentuk atau macam sanksi dari dunia internasional tersebut pula tidak diatur secara pasti oleh ketentuan tertentu. Karena hal ini berkaitan dengan hukum internasional, yang mana sumber hukum internasional salah satunya yaitu, customary (kebiasaan). Pemberian sanksi terhadap penolakan macam remedies oleh Indonesia dapat dikatakan sebagai suatu kebiasaan dalam ranah dunia internasional, karena dianggap tidak mematuhi kedudukan suatu putusan arbitrase yang bersifat final and binding tersebut.

${ }^{20}$ Amco Asia I Merits Award, 89 Int'1 L. Rep. at 456-59, 500-01.Ibid.[477]. 
Pada kasus Amco Asia v. Indonesia, dimana pemerintah Indonesia mengajukan permohonan pembatalan atas putusan arbitrase yang telah diputus oleh ICSID. Terhadap permohonan pembatalan ini Komite Ad Hoc kemudian membatalkan sebagian dari putusan tersebut. Walaupun, pemerintah Indonesia telah mencoba permohonan pembatalan putusan ini sebagai tindakan penolakan remedies yang dirasa merugikan, dalam kasus tersebut dinyatakan bahwa tetap saja pengadilan Komite Ad Hoc menyatakan aparat polisi dan militer Indonesia telah melanggar hukum.

Apabila dalam hal permohonan penolakan suatu putusan arbitrase ICSID diterima, maka akibat hukum yang dimungkinkan terjadi yaitu diasingkannya kedudukan negara dalam lingkup hukum internasional. Hal ini dimungkinkan terjadi karena menganggap bahwa negara tersebut telah mengabaikan kedudukan putusan ICSID yang bersifat internasional dan wajib dipatuhi oleh para pihak bersengketa.

\section{Upaya Hukum Pemerintah Indonesia terhadap Penolakan Remedies dalam Putusan Arbitrase Investasi}

Dalam kondisi terjadi penolakan remedies, maka hal ini akan berhubungan dengan prinsip lex mercatoria ${ }^{21}$ sebagai prinsip umum dalam hukum arbitrase internasional. Pada umumnya lex mercatoria ini akan berlaku apabila terjadi kekosongan hukum atas pengaturannya. Seperti misal dalam kondisi bahwa Indonesia tidak memiliki pengaturan seperti yang dibutuhkan untuk mengadili, maka pengadilan akan mengimplementasikan prinsip lex mercatoria secara seimbang. Seperti halnya dalam putusan arbitrase ICSID dalam kasus Amco Asia, atas permohonan Amco Asia tersebut, para pihak pada dasarnya tidak memiliki persetujuan mengenai aturan yang akan digunakan dalam penyelesaian sengketa mereka. Oleh karena itu, ICSID akhirnya menerapkan hukum Indonesia dalam menyelesaikan sengketa. Hal ini didasarkan pada kontrak yang dibuat para pihak dan

21 "A set of general principles, and customary rules spontaneously referred to or elaborated in the framework of international trade, whithout reference to a particular national system of law." (Okenzie Chukwumerije, Choice of Law in International Commercial Arbitration, Westport: Quorum Books, (1994)), dikutip pada Meria Utama, Lex Mercatoria sebagai Hukum yang di Pilih Dalam Penyelesaian Sengketa Dagang Internasional, Fakultas Hukum Universitas Sriwijaya, (2013).[13]. 
hukum internasional. ICSID juga menyatakan bahwa melihat yang dipersengketakan para pihak, maka terhadapnya dapat diterapkan hukum internasional. ${ }^{22}$ Sehingga dalam kasus ini diterapkannya lex mercatoria dalam menentukan penerapan hukum yang akan digunakan dalam penyelesaian sengketa Amco Asia.

\section{Perbandingan Pelaksanaan Remedies dalam Hukum Internasional dan Hukum Indonesia}

Bahwa pengakuan dan pelaksanaan suatu putusan arbitrase internasional hanya dapat dikabulkan apabila negara pemohon dengan Negara Indonesia terikat suatu perjanjian, baik secara bilateral maupun multilateral tentang pengakuan dan pelaksanaan putusan arbitrase internasional. ${ }^{23}$ Sehingga dalam hal ini secara jelas bahwa hubungan hukum internasional dengan hukum nasional, akan berlaku ketika Billateral Investment Treaty atau perjanjian invetasi lainnya berlaku bagi para pihak, seperti klausul arbitrase yang disebutkan diatas.

\section{Kesimpulan}

1) Eksistensi remedies dalam lingkup arbitrase internasional terkait investasi, pada umunya tertuang dalam substansi sebuah putusan yang dikeluarkan oleh ICSID (ICSID Award). Namun, dalam pengaturan ICSID Convention sendiri, belum terdapat ketentuan spesifik yang mengatur bentuk dan parameter pemberian remedies untuk diberikan kepada pihak yang kalah (losing party). Hanya saja, ketentuan yang terdapat dalam ICSID merupakan pengaturan khusus mengenai kewajiban pihak yang kalah untuk mematuhi dan melaksanakan kewajiban moneter atau pecuniary obligations atas putusan pengadilan ICSID. Sehingga, pada umumnya pengadilan ICSID hanya akan menggunakan parameter melalui seberapa besar kerugian yang dialami oleh pihak yang dirugikan dalam sengketa tersebut berdasarkan klausula-klausula yang telah dibentuk dalam investment

${ }^{22}$ Suleman Batubara dan Orinton Purba, Arbitrase Internasional, Raih Asa Sukses, Depok, (2013).[55].

${ }^{23}$ Suleman Batubara dan Orinton Purba, Arbitrase Internasional, Ibid.[203]. 
agreement; dan dengan metode tradisional atau non-tradisional.

2) Bentuk remedies dalam lingkup hukum investasi internasional terbagi dalam dua bentuk. Bentuk pertama yaitu pecuniary remedies. Dalam bentuk ini, remedies akan lebih mengarah pada lingkup monetary remedies atau kompensasi atas ganti kerugian yang dialami pihak yang dirugikan dalam proses investasi berlangsung. Bentuk kedua yaitu non-pecuniary remedies. Dalam bentuk ini yang sering diaplikasikan yaitu dalam bentuk restitusi aset pihak yang kalah. Namun dalam prakteknya, para investor asing atau pihak yang kalah akan lebih memilih untuk melaksanakan pecuniary remedies atau membayar dalam bentuk monetary remedies daripada restitusi aset mereka (non-pecuniary remedies).

3) Pelaksanaan remedies dalam penyelesaian sengketa investasi internasional, akan mengacu pada putusan pengadilan ICSID. Dimana karakteristik dari putusan tersebut adalah mengikat (binding) bagi para pihak bersengketa, sehingga atas remedies yang terdapat dalam putusan tersebut merupakan suatu kewajiban pihak yang kalah untuk dilaksanakan. Beberapa negara pada dasarnya memiliki mekanisme pelaksanaan putusan arbitrase yang berbeda dengan negara yang lainnya. Dalam lingkup Indonesia, misalnya pelaksanaan remedies atas putusan arbitrase ICSID akan melalui mekanisme pengakuan dan pelaksanaan. Dimana berdasarkan Undang-Undang No. 30 Tahun 1999 tentang Alternatif Penyelesaian Sengketa, intuk melaksanakan putusan arbitrase internasional terlebih dahulu harus didaftarkan kepada Pengadilan Negeri Jakarta Pusat untuk diakui (recognition).

4) Setelah dijatuhkannya remedies dalam putusan ICSID, pada umumnya tidak semua pihak yang kalah akan selalu menerima bentuk remedies yang diberikan. Sehingga dalam hal ini, terdapat dua kemungkinan yaitu ditolak atau diterima. Untuk menentukan suatu remedies yang diberikan tersebut akan dilaksanakan pihak yang kalah, negara tersebut akan menggunakan parameter state sovereignty atau kedaulatan negaranya. Apabila bentuk remedies tersebut tidak bertentangan dengan kedaulatan negara mereka, maka remedies atas putusan arbitrase internasional tersebut dapat diterima negara tersebut. Namun, apabila 
remedies tersebut melanggar kedaulatan suatu negara pihak yang kalah, maka dapat dimungkinkan negara tersebut akan menolak putusan arbitrase tersebut. Walaupun akibat hukum yang akan diterima pihak yang kalah apabila menolak atau menghiraukan remedies yang diberikan adalah dapat dalam bentuk diasingkannya negara terserbut dalam lingkup pelaksanaan hukum internasional.

\section{Daftar Bacaan}

\section{Buku}

Batubara, Suleman dan Orinton Purba. Arbitrase Internasional (Raih Asa Sukses, Depok 2013).

Dugan, Christopher F. and Don Wallace, Jr. Investor-State Arbitration (Oxford University Press 2017).

Gautama, Sudargo. Undang-Undang Arbitrase Baru 1999 (PT Citra Aditya Bakti Bandung 1999).

McLachlan QC, Campbell and Lauren Shore. International Investment Arbitration: Substantive Principles Second Edition (Oxford International Arbitration Series 2017).

Ripinsky, Sergey dan Kevin Williams. Damages in International Investment Law (British Institute of International and Comparative Law 2008).

\section{Jurnal}

Kaunang, Lydia. Penyelesaian Sengketa Penanaman Modal Menurut UndangUndang Nomor 25 Tahun 2007' (2017) Vol.V/No.6 Lex Privatum.

Kurniawan, Indra Tri. Arbitrase Internasional Sebagai Pilihan Forum dalam Penyelesaian Sengketa Kontrak Kerjasama Internasional, Skripsi Fakultas Hukum Universitas Airlangga (2012).

Noury, Sylvia, Remedies against states in investor-state arbitration - more bark than bite?, Freshfields Bruckhaus Deringer: BIICL Annual Conference (2009).

Smutny, Aby Cohen. Principles Relating to Compensation in The Investment Treaty Context, Investment Treaty Arbitration Workshop (2006).

Tjoanda, M. Wujud Ganti Rugi Menurut Kitab Undang-Undang Hukum Perdata, 
Jurnal Sasi Vol. 16 No. 4: Jurnal Universitas Pattimura, Oktober-Desember (2010).

Utama, Meria. Lex Mercatoria sebagai Hukum yang di Pilih Dalam Penyelesaian Sengketa Dagang Internasional, Fakultas Hukum Universitas Sriwijaya (2013).

\section{Karya Ilmiah}

Nurhadi, S.H. Pelaksanaan Putusan Arbitrase Internasional di Indonesia, Tesis Fakultas Hukum Universitas Airlangga (2005).

\section{Laman}

Investopedia, Comparable Transaction, <https: // www. investopedia.com/terms/c/ comparabletransaction.asp\#ixzz4zKv6rxc9>.

Kevin Smith, The Law Of Compensation For Expropriated Companies And The Valuation Methods Used To Achieve That Compensation, Paper Law \& Valuation: Professor Palmiter, 2001, <https://users.wfu.edu/palmitar/ Law\&Valuation/Papers/2001/Smith.htm>.

\section{Perundang-undangan}

International Centre for Settlement Investment Dispute (ICSID) Convention, yang telah diratifikasi oleh Pemerintah RI dengan diundangkannya (UndangUndang Nomor 5 Tahun 1968 tentang Persetujuan Indonesia Atas Penyelesaian Sengketa Penanaman Modal Asing Antara Pemerintah Indonesia Dengan Investor Asing).

Undang-Undang Nomor 25 Tahun 2007 tentang Penanaman Modal, Lembaran Negara RI Tahun 2007 Nomor 67.

Undang-Undang Nomor 30 Tahun 1999 tentang Altenatif Penyelesaian Sengketa, Lembaran Negara RI Tahun 1999 Nomor 138.

Convention on the Recognition and Enforcement of Foreign Arbitral Awards (New York Convention 1958).

HOW TO CITE: Amelia Maulanasari, 'Remedies Dalam Putusan Icsid Dalam Sengketa Investasi Internasional' (2018) Vol. 1 No. 1 JuristDiction. 